\title{
ASPIRASI PEREMPUAN DALAM PEMBENTUKAN PERATURAN DAERAH PROVINSI SULAWESI TENGGARA PERIODE 2014-2019 (Studi Pada Kantor DPRD Sulawesi Tenggara)
}

\author{
A Reski Amaliyah K ${ }^{1}$, Misran Safar ${ }^{2}$, Wa Ode Reni ${ }^{3}$ \\ Jurusan Pendidikan Pancasila dan Kewarganegaraan \\ Fakultas Keguruan dan Ilmu Pendidikan \\ Universitas Halu Oleo \\ Email: amaliyahkaresky@gmail.com ${ }^{1}$, misransafar18@gmail.com ${ }^{2}$ \\ reni@gmail.com ${ }^{3}$
}

\begin{abstract}
Abstrak: Tujuan penelitian ini: (1) untuk mengetahui aspirasi perempuan dalam pembentukan peraturan daerah di Provinsi Sulawesi Tenggara, (2)untuk mengetahui hambatan-hambatan apa yang dihadapi perempuan dalam memperjuangkan aspirasi perempuan di DPRD Provinsi Sulawesi Tenggara. Metode penelitian ini adalah kualitatif. Subyek penelitian ini adalah perempuan yang menjadi anggota legislatif di DPRD Provinsi Sulawesi Tenggara Periode 2014-2019 dan informan ketua DPRD, sekretaris DPRD, pimpinan fraksi, dan LSM. Teknik analisis data adalah deskriptif kualitatif. Hasil penelitian menunjukkan bahwa hanya terdapat 1 (satu) aspirasi perempuan yang menjadi produk legislatif Periode 2014-2019. Namun dalam peraturan daerah tersebut telah memuat berbagai aspek aspirasi perempuan terkait dengan perlindungan perempuan yakni hak-hak perempuan sebagai korban kekerasan baik sebagai tindakan pencegahan dan penanganan yang melibatkan tanggung jawab pemerintah, partisipasi masyarakat dan aparat hukum. Adapun aspirasi perempuan meliputi penciptaan rasa aman, hak perempuan sebagai korban berbagai bentuk perlindungan dan tanggung jawab pihak pemerintah. Namun demikian, masih terdapat berbagai hambatan yang dijumpai yang bekum dilakukan oleh lembaga legislatif DPRD Provinsi Sulawesi Tenggara Periode 2014-2019 dalam memperjuangkan aspirasi perempuan di berbagai sektor kehidupan sosial masyarakat seperti kendala masih kurangnya anggota legislatif perempuan, latar belakang pembentukan peraturan daerah DPRD Provinsi Sulawesi Tenggara anggota legislatif perempuan yang belum mengakomodir aktivis gerakan perempuan dan belum terbangunnya hubungan permanen antara legislatif dengan lembaga sosial gerakan perempuan. Kesimpulan penelitian ini adalah aspirasi perempuan di lembaga DPRD Provinsi Sulawesi Tenggara Periode 2014-2019 belum maksimal dan hanya terdapat 1 (satu) aspirasi perempuan yang menjadi produk aspirasi perempuan DPRD Provinsi Sulawesi Tenggara. Hambatan upaya pemenuhan aspirasi perempuan di DPRD Provinsi Sulawesi Tenggara adalah keterbatasan jumlah anggota legislatif perempuan, latar belakang sosial, dan penjaringan aspirasi perempuan.
\end{abstract}

Kata Kunci: Aspirasi Perempuan, Pembentukan Peraturan Daerah, DPRD Provinsi Sulawesi Tenggara

\section{PENDAHULUAN}

Konstitusi UUD 1945 menjamin bahwa setiap orang, laki-laki dan perempuan memiliki kedudukan yang sederajat dalam hukum dan pemerintahan, sehingga keduanya seharusnya memperoleh hak yang sama dalam kehidupan 
berbangsa dan bernegara. Namun kenyataannya, terkadang memperliatkan sebaliknya. Budaya patriarkhi yang lebih mengutamakan laki-laki daripada perempuan di ruang publik masih kuat dianut dalam kehidupan sosial masyarakat kita.

Undang-Undang Nomor 2 Tahun 2011 tentang Partai Politik yang mengatur keterwakilan perempuan 30\% dalam pencalonan anggota legislatif telah menunjukkan jaminan hukum terhadap kedudukan perempuan untuk berpartisipasi di ruang publik, yang selama ini terkesan hanya berada di ruang privat sebagai ibu rumah tangga saja. Padahal kaum perempuan merupakan bagian dari kehidupan sosial warga yang memiliki hak dan kewajiban yang sama dengan kaum laki-laki, sehingga tentu berhak pula untuk mendapatkan akses yang sama, berbagai contoh memperlihatkan bahwa keberadaan perempuan yang menjadi pimpinan lembaga pemerintahan dan swasta juga tidak mengecewakan, bahkan memiliki prestasi yang membanggakan, dibandingkan dengan kaum laki-laki.

Ini tentu saja diperlukan karena peran perempuan tidak bisa diabaikan dalam kehidupan sosial serta pembangunan bangsa dan negara kita. Catatan sejarah telah menunjukkan perjuangan kaum perempuan yang turut membangun dan membentuk kesadaran berbangsa dan bernegara. Seperti Raden Ajeng Kartini, Dewi Sartika, Cut Nyak Dien di Aceh. Begitu pula bahwa kehadiran kaum perempuan merupakan bagian tidak terpisahkan dengan keberadaan kaum lakilaki, sehingga hak yang sama tersebut harus diwujudkan.

Meskipun disadari pula bahwa belum semua pihak bisa menerima keberadaan perempuan di ruang publik, terutama pada mereka yang masih menganut budaya patriarkhi yang beranggapan bahwa laki-laki selalu lebih baik di banding kaum perempuan. Era demokrasi yang semakin maju telah menuntut kesetaraan tersebut sehingga secara politik bangsa kita juga telah berusaha mendorong partisipasi kaum perempuan di ruang publik, termasuk di dalamnya adalah dalam kelembagaan legislatif.

Kesadaran politik dalam era demokrasi juga telah tumbuh, warga masyarakat sebagai warga negara semakin sadar politik, bahwa kepedulian mereka terhadap politik diperlukan bagi kehidupan bersama, secara berkelanjutan oleh semua pihak. Tumbuhnya kesadaran ini memerlukan perhatian publik, bagi warga masyarakat itu sendiri maupun para elit politik, untuk secara sungguh-sungguh memberi dan membuka akses bagi kesadaran politik warga negara, termasuk kepada kaum perempuan.

Fenomena ini menarik untuk di teliti dari aspek kesadaran politik dengan alasan bahwa meningkatnya minat kaum perempuan di ruang publik tentunya terdapat alasan terhadap konsep kesadaran politik yang dimiliki oleh masingmasing anggota legislatif perempuan. Hal ini penting untuk dikaji lebih jauh, oleh karena di duga terdapat hubungan antara kesadaran politik yang dimilikinya dengan kinerjanya sebagai anggota legislatif ketika yang bersangkutan terpilih. Selain itu pula, hal ini semestinya dipahami lebih awal oleh konstituen masingmasing bagi proses demokrasi yang lebih baik.

\section{Konsep Perwakilan}

Uraian teori Perwakilan dikemukakan oleh Wahidin (2014:103) yang menyatakan bahwa teori klasik tentang akomodasi yang berkenaan dengan hubungan antara wakil dan terwakil dikenal pertama adalah teori mandat. Di dalam teori mandat ini pada dasarnya berasumsi bahwa substansi yang diwakili oleh 
seorang wakil terbatas pada mandat yang disampaikan oleh orang-orang yang memberikan mandat. Hal demikian mengharuskan segala tindakan, bahkan termasuk sikap dan perilaku dari wakil harus senantiasa bersesuaian dengan kehendak dari orang-orang yang memberikan mandat.

\section{Konsep Gender}

Konsep gender dikemukakan oleh Puspitawati (2012:211) yang menjelaskan bahwa istilah gender diperkenalkan oleh para ilmuwan sosial untuk menjelaskan perbedaan perempuan dan laki-laki yang bersifat bawaan sebagai ciptaan Tuhan dan yang bersifat bentukan budaya yang dipelajari dan disosialisasikan sejak kecil. Pembedaan ini snagat penting karena selama ini sering kali mencampur adukkan ciri-ciri manusia yang bersifat kodrati dan yang bersifat bukan kodrati (gender).

Perbedaan gender ini sangat membantu kita untuk memikirkan kembali tentang pembagian peran yang selama ini dianggap telah melekat pada manusia perempuan dan laki-laki untuk membangun gambaran relasi gender yang dinamis dan tepat serta cocok dengan kenyataan yang ada dalam masyarakat. Perbedaan konsep gender secara sosial telah melahirkan perbedaan peran perempuan dan lakilaki dalam masyarakatnya. Secara fungsi, dan bahkan tempat dimana manusia beraktivitas. Sedemikian rupanya perbedaan gender ini melekat pada cara pandang kita sehingga kita sering lupa seakan-akan hal itu merupakan sesuatu yang permanen dan abadi sebagaimana abadinya ciri biologis yang dimiliki oleh perempuan dan laki-laki.

Kata 'gender' diartikan sebagai perbedaan peran, fungsi, status, hak, tanggung jawab pada laki-laki dan perempuan sebagai hasil dari bentukan (konstruksi) sosial budaya yang tertanam lewat proses sosialisasi dari satu generasi ke generasi berikutnya. Dengan demikian gender adalah hasil kesepakatan antar manusia yang tidak bersifat kodrati. Oleh karenanya gender bervariasi dari satu tempat ke tempat lain dan dari satu waktu ke waktu berikutnya. Gender tidak bersifat kodrati, dapat berubah dan dapat dipertukarkan pada manusia ke manusia lainnya tergantung waktu dan budaya setempat.

\section{Konsep Aspirasi Perempuan}

Menurut Rodiyah (2013:218) mengemukakan bahwa, kaum perempuan diberi keleluasaan untuk bergabung ke dalam berbagai partai politik dan organisasi perempuan lain sehingga memiliki ruang memadai untuk menyalurkan aspirasinya. Namun demikian, sering kali keterlibatan perempuan sangat terbatas pada area yang sangat sempit, tidak ada kemandirian, serta tidak memiliki dampak langsung dalam menghasilkan kebijakan publik. Akibat rendahnya angka keterwakilan perempuan di parlemen, menyebabkan banyak aspirasi perempuan tak terakomodir pemerintah.

\section{Konsep Hambatan}

Wibowo (2009:10) hambatan adalah sebuah halangan, rintangan, atau suatu keadaan yang tidak di kehendaki atau disukai kehadirannya, menghambat perkembangan seseorang menimbulkan kesulitan baik bagi diri sendiri maupun orang lain dan ingin atau perlu dihilangkan. Hambatan terdiri atas 2 (dua) faktor, pertama faktor internal dan faktor eksternal. Faktor internal adalah hal-hal atau keadaan-keadaan yang datang dari luar diri individu itu sendiri. Faktor eksternal adalah hal-hal atau keadaan-keadaan yang datang dari luar individu itu sendiri. Setiap hal yang muncul baik dari dalam diri maupun dari luar diri yang bersifat 
menghambat perkembangan dan membuat kesulitan baik buat diri sendiri maupun orang lain merupakan faktor penghambat.

\section{METODE PENELITIAN}

\section{Lokasi dan Waktu Penelitian}

Penelitian ini dilakukan di Kantor DPRD Provinsi Sulawesi Tenggara bulan Maret-Mei. Alasan pemilihan lokasi, karena obyek penelitian aspirasi perempuan berada pada Kantor DPRD Provinsi Sulawesi Tenggara dan jumlahnya cukup memadai yakni 8 (delapan) orang.

\section{Jenis Penelitian}

Jenis penelitian ini adalah penelitian kualitatif, yakni akan mengidentifikasi aspirasi perempuan dalam kelembagaan DPRD Provinsi Sulawesi Tenggara. Hal tersebut akan di teliti secara kualitatif yakni akan menganalisis berbagai aspek terhadap kecenderungan aspirasi perempuan dalam kelembagaan legislatif.

\section{Subyek Penelitian}

Subyek penelitian ini terdiri dari responden dan informan. Responden dalam penelitian ini adalah perempuan yang menjadi anggota DPRD Provinsi Sulawesi Tenggara sebanyak 4 (empat) orang. Informan dalam penelitian ini adalah berbagai pihak yang memiliki pengetahuan terhadap kinerja anggota DPRD perempuan Provinsi Sulawesi Tenggara (Ketua DPRD, Sekretaris DPRD dan Pimpinan fraksi) sebanyak 9 (sembilan) orang.

\section{Teknik Pengumpulan Data}

Observasi, yaitu dilakukan dengan pengamatan terhadap aktivitas anggota DPRD perempuan Provinsi Sulawesi Tenggara Periode 2014-2019 dalam pembahasan mengenai peraturan daerah (perda)

Wawancara, yaitu dilakukan terhadap responden dan informan yang memahami aktivitas anggota DPRD perempuan Provinsi Sulawesi Tenggara dan hambatan-hambatan yang dihadapi perempuan dalam memperjuangkan aspirasinya.

Dokumentasi, yaitu dilakukan dengan mengumpulkan data aspirasi perempuan dan hambatan-hambatan yang dihadapi perempuan dalam memperjuangkan aspirasinya.

\section{Teknik Analisis Data}

Teknik analisis data yang digunakan dalam penelitian ini adalah deskriptif kualitatif, yakni akan mengemukakan berbagai faktor terhadap aspirasi perempuan dalam lembaga legislatif yang akan diuraikan secara deskriptif.

\section{HASIL DAN PEMBAHASAN}

\section{Aspirasi Perempuan Dalam Pembentukan Peraturan Daerah Provinsi} Sulawesi Tenggara Periode 2014-2019

Dalam penelitian yang dilakukan terutama melalui wawancara dan dokumentasi baik kepada anggota legislatif perempuan dan informan yakni pimpinan DPRD Provinsi Sulawesi Tenggara ditemukan bahwa aspirasi perempuan yang terdapat dalam Periode 2014-2019 belum maksimal dan hanya terdapat 1 (satu) aspirasi perempuan dalam bentuk fungsi legislasi peraturan daerah, yakni peraturan daerah Nomor 4 Tahun 2018 tentang Perlindungan Perempuan dan Anak Korban Kekerasan 
Adapun pembahasan mengenai peraturan daerah perlindungan perempuan dan anak korban kekerasan sebagai aspirasi perempuan sebagaimana dimaksud dalam penelitian ini akan diuraikan pada beberapa aspek pembahasan antara lain mencakup:

a. Konsep Perlindungan Perempuan

b. Ruang Lingkup Perlindungan Perempuan

c. Hak Perempuan Sebagai Korban

d. Kewajiban dan Tanggung Jawab Pemerintah Daerah, Masyarakat, Keluarga, dan Orang Tua dan Penyelenggaraan Perlindungan

Beberapa poin pokok pembahasan tersebut yang menjadi analisis terhadap aspirasi perempuan yang terdapat pada peraturan daerah dimaksud, yang akan diuraikan satu per satu, yakni:

Pembahasan aspirasi perempuan yang menjadi obyek penelitian ini dengan berdasar pada konsep aspirasi perempuan yang telah dikemukakan oleh Isnaini Rodiyah bahwa aspirasi perempuan sebagai pemenuhan hak-hak perempuan menjadi pijakan dalam melihat konsep perlindungan perempuan. Dari rumusan konsep perlindungan perempuan menunjukkan beberapa aspek yakni; pertama bahwa perlindungan perempuan ditujukkan untuk memberikan rasa aman, kedua sebagai akibat tindak kekerasan terhadap perempuan, dan ketiga bahwa perlindungan tersebut diberikan oleh lembaga berwenang (Kepolisian, Kejaksaan, Pengadilan, dan Lembaga Sosial).

Adapun ruang lingkup perlindungan perempuan sebagaimana diatur dalam peraturan daerah tersebut adalah meliputi tindakan pencegahan tindak kekerasan;

a. Pencegahan tindak kekerasan

b. Pelayanan terpadu bagi korban, dan

c. Pemberdayaan terhadap korban tindak kekerasan

Aspirasi tersebut mengggambarkan upaya perlindungan perempuan bukan saja ditujukkan pada penanganan terjadinya tindak kekerasan, tetapi juga mencakup upaya pemberdayaan terhadap korban tindak kekerasan. Dengan akibat seperti itu maka kedudukan perempuan sangat lemah jika tidak dapat di bantu dengan upaya pemberdayaan.

Aspirasi perempuan yang memberi perhatian pada perlindungan perempuan sebagaimana tertuang dalam peraturan daerah tersebut memperlihatkan luasnya aspek yang menjadi bagian yang dikategorikan sebagai hak korban sebagaimana diuraikan dalam Pasal 8 sebagai berikut:

Korban berhak mendapat:

a. Perlindungan dari pihak keluarga, kepolisian, kejaksaan, pengadilan, advokat, lembaga sosial, atau pihak lainnya baik sementara maupun penetapan perintah perlindungan dari pengadilan

b. Pelayanan terpadu berupa: pelayanan pengaduan, pelayanan kesehatan, konseling, bimbingan rohani, pelayanan rehabilitasi sosial, pelayanan bantuan dan pendampingan hukum;dan/atau pemulangan dan reintegrasi

Kewajiban dan tanggung jawab perlindungan korban dipahami sebagai tanggung jawab bersama yang melibatkan pemerintah, masyarakat, keluarga, dan orang tua. Uraian aspirasi perempuan menunjukkan besarnya tanggung jawab pemerintah daerah yang semestinya dilakukan dengan menyediakan baik saran, prasarana yang bukan saja melakukan penanganan kejadian tetapi hingga penanganan berlanjut. 


\section{Hambatan-Hambatan yang dihadapi perempuan dalam memperjuangkan aspirasi perempuan di DPRD Provinsi Sulawesi Tenggara Periode 2014-2019}

1. Keterbatasan Jumlah Anggota Legislatif Perempuan

2. Latar Belakang Anggota Legislatif Perempuan di DPRD Provinsi Sulawesi Tenggara

3. Penjaringan Aspirasi Perempuan

Keterbatasan jumlah legislatif perempuan sebagai salah satu faktor yang mempengaruhi representasi aspirasi perempuan di DPRD Provinsi Sulawesi Tenggara Periode 2014-2019. Jika dibandingkan dengan jumlah anggota legislatif laki-laki yang berjumlah 36 orang maka terdapat $18 \%$ keanggotaan legislatif perempuan dibandingkan dengan anggota legislatif laki-laki, sedangkan jumlah keanggotaan laki-laki sebanyak 36 orang mendominasi $81 \%$ dari total 44 anggota legislatif. Jumlah tersebut memperlihatkan bahwa dominasi kaum legislatif lakilaki memiliki jumlah yang jauh lebih banyak.

Bagian latar belakang aktivis sosial sebagai salah satu aspek yang dipandang memberi pengaruh baik sebagai daya dukung atau faktor positif juga merupakan aspek yang bisa menjadi salah satu pengaruh terhadap hambatanhambatan aspirasi perempuan di lembaga legislatif di DPRD Provinsi Sulawesi Tenggara Periode 2014-2019. Aktivitas sosial yang dimiliki anggota legislatif perempuan berlatar belakang sebagai istri mantan bupati sehingga terlihat bahwa aktivitas sosial yang digeluti merupakan aktivitas yang melekat pada jabatan yang ada pada jabatan suami yakni, sebuah organisasi Ketua Tim PKK. Dari aspek tersebut dapat dinilai bahwa anggota legislatif perempuan sebagaimana telah diuraikan sebenarnya telah memiliki pemahaman terhadap berbagai hak-hak yang melekat pada perempuan.

Dari hasil penelitian tentang penjaringan aspirasi perempuan ternyata upaya untuk menyerap aspirasi perempuan yang dilakukan atau seharusnya dilakukan oleh angggota legislatif perempuan DPRD Provinsi Sulawesi Tenggara Periode 2014-2019 tidak dilakukan.

\section{PENUTUP}

\section{Kesimpulan}

1. Aspirasi perempuan dalam pembentukan peraturan daerah di DPRD Provinsi Sulawesi Tenggara Periode 2014-2019 belum maksimal, bahwa dari 40 peraturan daerah di DPRD hanya terdapat 1 (satu) aspirasi perempuan yang menjadi produk aspirasi perempuan DPRD Provinsi Sulawesi Tenggara. Perda tersebut memuat semua aspek terhadap perlindungan perempuan sebagai korban kekerasan yang meliputi aspirasi, rasa aman, hak perempuan sebagai korban, dan tanggung jawab pemerintah.

2. Hambatan-hambatan yang terdapat pada upaya pemenuhan aspirasi perempuan di DPRD Provinsi Sulawesi Tenggara antara lain adalah keterbatasan jumlah anggota legislatif perempuan, latar belakang sosial anggota legislatif perempuan DPRD Provinsi Sulawesi Tenggara Periode 2014-2019, dan penjaringan aspirasi perempuan.

\section{Saran}

1. Bagi pemerintah dan DPRD sebaiknya melakukan hubungan eksternal secara berkelanjutan dalam menjaring aspirasi perempuan dengan berbagai pihak 
terutama organisasi aktivis perempuan agar dapat memelihara issu-issu aspirasi perempuan yang berkembang di masyarakat.

2. Masyarakat perlu secara aktif untuk senantiasa menyampaikan aspirasiaspirasi perempuan yang terjadi sehingga dapat diketahui. Hal ini dapat dilakukan melalui saluran-saluran media sosial yang telah berkembang luas sehingga kesadaran aspirasi perempuan sebagai hak-hak warga Negara dapat dipahami secara luas.

\section{DAFTAR PUSTAKA}

Puspitawati, H. 2012. Gender Dan Keluarga: Konsep dan Realita di Indonesia. Bogor: PT IPB Press

Rodiyah, Isnaini. 2013. https://scholar.google.co.id Keterwakilan Perempuan Dalam Lembaga Dewan Perwakilan Rakyat Daerah, Volume 1 Number 1.

Undang-Undang Nomor 2 Tahun 2011 tentang Partai Politik

Wahidin, Samsul. 2014. Distribusi dan Kekuasaan Negara Indonesia.

Wibowo Dian Utomo. 2009. https://repository.usd.ac.id Hambatan, Motivasi, Dan Strategi Pemecahan Masalah Pada Mahasiswa Psikologi Universitas Sanata Dharma Yang Sedang Mengerjakan Skripsi 